Website: http://journal.umy.ac.id/index.php/mrs

DOI: $10.18196 / \mathrm{jmmr} .6126$

\title{
Evaluasi Pelaksanaan Supervisi Keperawatan di Rumah Sakit Umum Daerah Panembahan Senopati Bantul
}

\author{
Dini Desi Harmatiwi*, Sri Sumaryani, Elsye Maria Rosa \\ *Penulis Korespondensi: dini.dharmawati@gmail.com \\ Program Manajemen Rumah Sakit Universitas Muhammadiyah Yogyakarta

\begin{tabular}{l}
\hline INDEXING \\
\hline Keywords: \\
Nursing; Supervision; \\
Hospital
\end{tabular}

A B S T R A C T
The purpose of this study is to evaluate the implementation of the supervision of nursing in Panembahan
Senopati Bantul Hospital. This study is a descriptive qualitative research. All data derived from
interviews, observation, and search documents. Sample of respondents is representative of the nursing
supervisor scheduled in October 2015. The research variables: the implementation of nursing
supervision, seen from the description of the implementation, engineering, area, barriers of
implementation, supervision and evaluation program monitor. Of the 67 times the supervision
scheduled in October 2015 only 17 were implemented (25.4\%). Figures noncompliance supervisor in
the execution of supervision is still quite high. The majority of supervisors do with indirect supervision.
Supervision has not been carried out throughout the area should be. Barriers to implementation of
supervision include external and internal obstacles. Program monitoring and evaluation of supervision
is still not implemented. Supervision of nursing has not gone up, judging from the absence rate of non-
compliance supervisor and implementation is quite high, and there are still incomprehension
supervisor of engineering and supervisory area should be.

Kata kunci:

Keperawatan; Supervisi;

Rumah Sakit

\begin{abstract}
Tujuan penelitian ini untuk mengevaluasi pelaksanaan supervisi keperawatan di RSUD Panembahan Senopati Bantul. Penelitian ini merupakan penelitian kualitatif deskriptif. Seluruh data berasal dari hasil wawancara ,observasi, dan telusur dokumen. Sampel responden adalah perwakilan supervisor keperawatan Variabel penelitian yakni pelaksanaan supervisi keperawatan, yang dilihat dari gambaran pelaksanaan, teknik, area, hambatan pelaksanaan, serta program monitor evaluasi supervisi. Angka ketidakpatuhan supervisor dalam pelaksanaan supervisi masih cukup tinggi. Supervisi belum dilakukan keseluruh area yang seharusnya. Hambatan pelaksanaan supervisi meliputi hambatan eksternal dan internal. Program monitor dan evaluasi supervisi masih belum dilaksanakan. Supervisi keperawatan belum berjalan dengan maksimal, dilihat dari angka ketidakhadiran supervisor dan ketidakpatuhan pelaksanaan yang cukup tinggi, serta masih terdapat Kebelumpahaman kebelumpahaman supervisor tentang teknik dan area supervisi yang seharusnya.
\end{abstract}

(C) 2017 JMMR. All rights reserved

$\overline{\text { Article history: received } 25}$ Agu 2016; revised 19 Nov 2016; accepted 15 Nov 2016

\section{PENDAHULUAN}

Keperawatan seperti yang telah disebutkan di atas, adalah salah satu profesi yang memegang peranan penting dalam upaya menjaga mutu pelayanan kesehatan di rumah sakit karena merupakan penghasil aktivitas terbesar yang mencerminkan mutu pelayanan -1 . Tenaga perawat mempunyai kedudukan penting dalam menghasilkan kualitas pelayanan kesehatan di rumah sakit karena pelayanan yang diberikannya merupakan pelayanan unik, yang mencakup aspek bio-psiko-sosialspiritual yang diberikan selama 24 jam dan berkesinambungan dimana hal ini merupakan kelebihan tersendiri dibandingkan dengan pelayanan lainnya ${ }^{-}$. Perawat juga merupakan kelompok pemberi jasa pelayanan dengan jumlah terbesar di rumah sakit, yakni mencapai 40-60\%.?

Banyak hal yang dapat dilakukan sebagai upaya untuk menjaga mutu pelayanan kesehatan termasuk pelayanan keperawatan. salah satunya dengan supervisi. Supervisi merupakan upaya untuk membantu pembinaan dan peningkatan kemampuan pihak yang disupervisi agar mereka dapat melaksanakan tugas kegiatan yang telah ditetapkan dengan efektif dan efisien ${ }^{17}$. Supervisi keperawatan adalah kegiatan 
pengawasan dan pembinaan yang dilakukan berkesinambungan oleh supervisor.

Supervisi dalam konteks keperawatan dipahami sebagai suatu proses kegiatan pemberian dukungan sumber-sumber yang dibutuhkan perawat dalam rangka menyelesaikan tugas untuk mencapai tujuan yang telah ditetapkan. Pelaksanaan supervisi bukan hanya ditujukan untuk mengawasi apakah seluruh staf keperawatan menjalankan tugasnya dengan sebaik-baiknya, sesuai dengan instruksi atau ketentuan yang telah digariskan, tetapi juga bagaimana memperbaiki proses keperawatan yang sedang berlangsung. Kegiatan supervisi yang baik menjadikan seluruh staf keperawatan bukan sebagai obyek tetapi juga sebagai subyek. Perawat diposisikan sebagai mitra kerja yang memiliki ide-ide, pendapat, dan pengalaman yang perlu didengar, dihargai dan diikutsertakan dalam melakukan asuhan keperawatan-1.

Kegiatan supervisi yang tidak dilakukan dengan baik akan memberikan dampak bagi kinerja perawat pelaksana juga terjadinya pemberian layanan kesehatan yang menurun atau tidak optimal sehingga dapat muncul kecenderungan akan adanya kejadian yang tidak diharapkan atau nyaris cedera yang bertentangan dengan pasient safety. Sesuai dengan penelitian Nainggolan (2010), penurunan kinerja perawat akan mempengaruhi mutu pelayanan kesehatan. $\frac{15}{}$

Pembentukan tim supervisor di RSUD Panembahan Senopati Bantul merupakan upaya penjaminan mutu pelayanan keperawatan kepada pasien. Akan tetapi berdasarkan pengalaman dan pengamatan dari peneliti selama pernah menjalani program pendidikan dokter sebagai co-assistant selama 2 tahun di RSUD Panembahan Senopati Bantul pada 2011-2012, pelaksanaan supervisi belum berjalan dengan baik sebagaimana yang diharapkan. Jadwal supervisi yang telah ditetapkan untuk setiap supervisor keperawatan tiap bulannya pun belum terlaksana optimal. Hal ini dapat dilihat dari pelaksanaan supervisi keperawatan pada 3 bulan yang diamati peneliti yakni pada bulan Juni-Agustus 2015 dimana pelaksanaannya belum optimal. Pelaksanaan supervisi keperawatan pada bulan Juni 2015, dari 69 kali terjadwal hanya 22 kali terealisasi sementara pada Juli 2015, terdapat 24 kali pelaksanaan supervisi keperawatan dari 68 kali terjadwal, dan pada Agustus 2015 terdapat 19 kali pelaksanaan supervisi keperawatan dari 68 kali terjadwal. Rumusan masalah dari penelitian ini adalah
"Bagaimana pelaksanaan supervisi keperawatan di RSUD Panembahan Senopati Bantul?

\section{METODE PENELITIAN}

Penelitian ini merupakan jenis penelitian kualitatif dengan desain deskriptif, dengan melakukan telusur dokumen, observasi pelaksanaan supervisi dan wawancara dengan perwakilan supervisor. Penelitian ini bertujuan untuk mengevaluasi pelaksanaan supervisi keperawatan di RSUD Panembahan Senopati Bantul.

Populasi pada penelitian ini adalah seluruh supervisor yang terjadwal dalam kegiatan supervisi di RSUD Panembahan Senopati Bantul pada bulan Oktober 2015. Sampel penelitian berdasarkan kriteria inklusi meliputi semua supervisor yang terjadwal dalam kegiatan supervisi bulan Oktober 2015, dengan kriteria eksklusi yakni supervisor yang tidak berangkat pada tanggal pelaksanaan supervisi dari jadwal supervisi dilakukan pula yakni kepada Kepala Seksi Keperawatan dan Kebidanan.

Populasi dan sampel untuk wawancara perwakilan supervisor dilakukan dengan teknik purposive sampling. Penentuan jumlah sampel dilakukan berdasarkan acuan sampel pada penelitian serupa sebelumnya serta dengan perhitungan rumus Slovin untuk jumlah populasi yang telah diketahui, yakni:

$$
\mathrm{n}=\mathrm{N} /(1+\mathrm{Nd} 2),
$$

dimana $\mathrm{n}=$ jumlah sampel yang dicari ; $\mathrm{N}=$ ukuran populasi yang diketahui; $d=$ presisi margin error $(5 \%)$.

Penelitian Ahaddyah (2012) menggunakan 3 supervisor sebagai responden penelitian, dengan jumlah populasi supervisor sebanyak 31 di RSUD Kota Depok yang menjadi lokasi penelitian. Populasi supervisor yang terjadwal pada Oktober 2015 di RSUD Panembahan Senopati Bantul adalah 39 orang, sehingga bila dihitung dengan rumus Slovin di atas menghasilkan hasil akhir perhitungan 3,62 yang dibulatkan menjadi 3 sampel yang akan menjadi responden untuk diwawancarai sebagai perwakilan supervisor. $\stackrel{2}{ }$ Hasil ini pun serupa dengan jumlah sampel dari penelitian sebelumnya. 
Variabel dalam penelitian ini adalah pelaksanaan supervisi keperawatan di RSUD Panembahan Senopati Bantul, dengan lima subvariabel, yaitu gambaran pelaksanaan, teknik, area, hambatan pelaksanaan, dan program monitoring evaluasi supervisi keperawatan. Analisis data penelitian dilakukan melalui analisis data kualitatif dan disajikan dalam bentuk naratif. Wawancara dengan perwakilan pihak manajemen untuk menunjang informasi.

\section{HASIL DAN PEMBAHASAN}

\section{Hasil Observasi}

Data-data hasil observasi disajikan pada tabel 1,2 dan 3. Observasi dilakukan sebanyak 17 kali kegiatan sesuai dengan hasil observasi supervisi dapat dilihat pada tabel 3. Hasil observasi pelaksanaan supervisi keperawatan seperti pada tabel 3 di atas memberi gambaran bahwa telah diamati pelaksanaan supervisi pada Oktober 2015 sebanyak 17 kali observasi moment dengan masing-masing observasi terdiri dari 15 poin checklist pengamatan. Sebanyak 6 poin dilakukan oleh semua supervisor $(100 \%)$ dari 17 kali pelaksanaan supervisi pada Oktober 2015 tersebut, yakni pada poin pemeriksaan petugas jaga, list serah terima pasien pada rekam medis, format pendidikan kesehatan, form penilaian nyeri, dan kegiatan pengisian serta pelaporan hasil usai supervisi. Hal ini berarti tingkat kepatuhan supervisor sebesar $100 \%$ ada pada 6 poin tersebut, sedangkan sisanya yakni 9 poin penilaian lainnya kurang dari 100 persen yang diartikan sebagai ketidakpatuhan. Tingkat ketidakpatuhan yang paling buruk ada pada poin serah terima jaga antar petugas supervisi, dimana dari 17 kali pelaksanaan supervisi yang dilakukan Oktober 2015 tidak pernah ada satupun pelaksanaan serah terima jaga antar petugas $(0 \%)$.

\section{Gambaran Pelaksanaan Supervisi Keperawatan di RSUD Panembahan Senopati Bantul}

Berdasarkan hasil penelitian yang telah didapatkan, diperoleh data bahwa supervisi keperawatan di RSUD Panembahan Senopati Bantul pada bulan Oktober 2015 dijadwalkan sebanyak 67 kali supervisi dan pada kenyataannya hanya dilaksanakan sebanyak
17 kali (25,4\%). Jadwal supervisi yang tidak dilaksanakan sebanyak 50 kali (74,6\%).

Tabel 1. Tabel Persentase Realisasi Jadwal Jaga Supervisor Keperawatan Bulan Juni-Agustus 2015

\begin{tabular}{cccc}
\hline Bulan & Jadwal Jaga & Realisasi & Persentase \\
\hline Juni & 69 & 22 & $32,35 \%$ \\
Juli & 68 & 24 & $35,29 \%$ \\
Agustus & 68 & 19 & $27,94 \%$ \\
\hline
\end{tabular}

Sumber: Bidang Keperawatan RSUD Panembahan Senopati

Tabel 2. Karakteristik Supervisior Bulan Oktober

2015 Berdasarkan Usia, Jenis Kelamin, dan

Tingkat Pendidikan di RSUD Panembahan

Sinopati Bantul $(\mathbf{n}=39)$

\begin{tabular}{lcc}
\hline Karakteristik & Jumlah & Persentase \\
\hline Usia & & \\
30-40 tahun & 31 & $20,5 \%$ \\
$\quad$ 40-50 tahun & & $79,5 \%$ \\
Jenis Kelamin & 12 & $30,8 \%$ \\
$\quad$ Laki-laki & 27 & $69,2 \%$ \\
$\quad$ Perempuan & & \\
Tingkat Pendidikan & 14 & $35,9 \%$ \\
$\quad$ D3 & 22 & $56,4 \%$ \\
S1 & 3 & $5,1 \%$ \\
S2 & &
\end{tabular}

Sumber: Bidang Keperawatan RSUD Panembahan Senopati

Tabel 3. Pelaksanaan Supervisi Keperawatan bulan Oktober 2015 di RSUD Panembahan Senopati Bantul

\begin{tabular}{ccc}
\hline $\begin{array}{c}\text { Pelaksanaan } \\
\text { Supervisi }\end{array}$ & $\begin{array}{c}\text { Jumlah } \\
\text { Pelaksanaan }\end{array}$ & Persentasi \\
\hline Ya & 17 & $25,4 \%$ \\
Tidak & 50 & $74,6 \%$ \\
\hline
\end{tabular}

Sumber: Bidang Keperawatan RSUD Panembahan Senopati

Penelitian yang telah dilakukan Supratman \& Sudaryanto (2008) menyimpulkan bahwa pelaksanaan supervisi di berbagai rumah sakit belum optimal $\stackrel{21}{-}$. Hal ini juga sejalan dengan penelitian Mua (2011) yang mengemukakan bahwa tidak optimalnya supervisi klinik kepala ruangan harus mendapat perhatian yang serius dari bidang keperawatan, mengingat resiko dan dampak yang dapat timbul berkaitan dengan supervisi klinik kepala ruangan yang tidak optimal yaitu pelayanan keperawatan yang tidak berkualitas ${ }^{14}$. Ketidakoptimalan supervisi termasuk 
dalam hal ketidakhadiran supervisor dan ketidakefektifitasan supervisi.

Informasi lain mengenai tingginya angka ketidakhadiran supervisor diperoleh dari Kepala Seksi Keperawatan dan Kebidanan yang berpendapat bahwa hal tersebut dikarenakan beban kerja ganda yang diemban oleh supervisor. Belum terdapat supervisor yang independent atau berdiri sendiri. Mayoritas supervisor di RSUD Panembahan Senopati Bantul adalah kepala ruangan, atau perawat pelaksana senior, dimana mereka tentu saja selain sebagai supervisor memiliki tugas lain sesuai dengan jabatannya. Hal ini menyebabkan beban kerja ganda, yang berdampak pada ketidakhadiran supervisor pada jadwal yang telah ditentukan.

Gambaran pelaksanaan supervisi lain diperoleh dari hasil observasi menggunakan checklist observasi tabel 4.3. Pelaksanaan supervisi pada Oktober 2015 sebanyak 17 kali observasi momen dengan masingmasing observasi terdiri dari 15 poin checklist pengamatan. Sebanyak 6 poin dilakukan oleh semua supervisor (100\%) dari 17 kali pelaksanaan supervisi pada Oktober 2015 tersebut, yakni pada poin pemeriksaan petugas jaga, list serah terima pasien pada rekam medis, format pendidikan kesehatan, form penilaian nyeri, dan kegiatan pengisian serta pelaporan hasil usai supervisi. Hal ini berarti tingkat kepatuhan supervisor sebesar $100 \%$ ada pada 6 poin tersebut, sedangkan sisanya yakni 9 poin penilaian lainnya kurang dari 100 persen yang diartikan sebagai ketidakpatuhan. Tingkat ketidakpatuhan yang paling buruk ada pada poin serah terima jaga antar petugas supervisi, dimana dari 17 kali pelaksanaan supervisi yang dilakukan Oktober 2015 tidak pernah ada satupun pelaksanaan serah terima jaga antar petugas $(0 \%)$.

Kepatuhan (compliance) merupakan bentuk perilaku yang ditujukan terhadap suatu objek, dalam penelitian ini berupa tugas supervisor yang dinilai menggunakan checklist yang dibuat berdasarkan pada SOP peraturan rumah sakit terkait supervisi. Kepatuhan sendiri merupakan salah satu bentuk perilaku yang dapat dipengaruhi oleh faktor internal maupun eksternal, dimana menurut Siregar (2006) faktor internal tersebut meliputi pengetahuan, masa kerja, motivasi, pendidikan, usia, jenis kelamin, dan sikap, sedangkan faktor eksternal diantaranya berupa penghargaan misalnya honorarium, sistem reward- punishment, ketersediaan fasilitas, peraturan terkait, dan pengawasan dari atasan $\underline{20}$.

Hasil penelitian memberikan gambaran tentang kepatuhan perawat dalam melaksanakan SOP masih kurang. Hal tersebut dibuktikan dengan masih tingginya nilai ketidakpatuhan dalam checklist observasi. Faktor yang mempengaruhi kinerja perawat terhadap kepatuhan pelaksanaan SOP yakni usia, lama kerja, tingkat pendidikan, motivasi dan persepsi ${ }^{16}$. Penelitian terkait yang dilakukan Badi'ah (2009) menyebutkan bahwa secara umum faktor motivasi memiliki hubungan yang kuat dengan kinerja, termasuk dalam hal ini adalah kepatuhan terhadap SOP rumah sakit ${ }^{3}$. Hal yang dapat diprediksi adalah yakni bila motivasi meningkat maka kinerja juga akan meningkat. Penelitian lainnya menyatakan bahwa motivasi kerja juga berpengaruh positif terhadap kepuasan kerja dan dengan pemberlakuan sistem reward-punishment terhadap karyawan akan mempengaruhi kinerja 10 .

Kepala Bidang Keperawatan dan Kebidanan RSUD Panembahan Senopati Bantul menyatakan bahwa angka ketidakpatuhan yang tinggi disebabkan juga oleh supervisor yang tidak independen. Supervisor yang tidak independen, dalam hal ini misalnya merangkap sebagai kepala ruang dari bangsal yang sedang disupervisi, tentu saja akan mengakibatkan tingkat objektifitas yang menurun juga. Supervisor bisa jadi merasa tidak perlu melakukan penilaian lengkap seperti pada uraian tugas yang ditetapkan karena rasa canggung kepada rekan-rekan dalam unit yang sama, yang setiap hari juga tentu mengetahui kinerja dan keseharian dari supervisor yang sedang melakukan supervisi.

Faktor non-independent tersebut juga dapat mengakibatkan ketidakpatuhan yang bersumber oleh faktor ketidakefektifitasan proses supervisi. Supervisor yang merangkap sebagai kepala ruang di unit yang sedang disupervisi, tentu saja berpotensi lebih besar untuk lebih banyak menghabiskan waktu selama proses supervisi untuk melakukan hal-hal yang tidak efektif, misalnya mengobrol dengan para perawat yang seharihari menjadi rekan kerja di unit atau bangsal tersebut. Asumsi peneliti bahwa jika pihak manajemen rumah sakit mampu memperhatikan dan mengelola faktor yang mempengaruhi kepatuhan dalam menjalankan SOP seperti yang telah disebutkan di atas, maka potensi supervisor untuk melakukan kegiatan supervisi dengan lebih baik dan patuh juga akan lebih besar. 


\section{Teknik Supervisi}

Hasil penelitian tentang teknik supervisi diperoleh berdasarkan hasil wawancara dengan perwakilan supervisor dan hasil checklist peneliti pada poin 4-14. Berikut ini adalah hasil coding wawancara yang disajikan dalam Tabel 4.

Tabel 4. Hasil Coding Wawancara Teknik Supervisi

\begin{tabular}{|c|c|c|}
\hline Keterangan & Axial Coding (Subtema) & Tema \\
\hline \multirow{7}{*}{ Responden 1} & Mengecek catatan asuhan & \\
\hline & keperawatan pada rekam & \\
\hline & medis. & \\
\hline & Bertanya pada perawat & \\
\hline & tentang kondisi bangsal & \\
\hline & Mengamati pelaksanaan & \\
\hline & pelayanan keperawatan & \\
\hline \multirow{17}{*}{ Responden 2} & Menerima laporan lisan & \\
\hline & dari perawat tentag & \\
\hline & kondisi bangsal & \\
\hline & Mengecek catatan askep & \\
\hline & pada rekam medis tentang & \\
\hline & kondisi pasien hari demi & \\
\hline & hari & Supervise \\
\hline & Memeriksa kelengkapan & dilakukan \\
\hline & dokumentasi pasien mulai & sekaligus \\
\hline & dari UGD/poli, serah & dengan \\
\hline & terima pasien, lembar & teknik \\
\hline & resiko jatuh, & langsung \\
\hline & lembarpenilaian lainnya. & dan tidak \\
\hline & Mendampingi perawat & langsung \\
\hline & dalam mengisi & \\
\hline & dokumentasi asuhan & \\
\hline & keperawatan & \\
\hline \multirow{10}{*}{ Responden 3} & Memeriksa kelengkapan & \\
\hline & rekam medis pasien dan & \\
\hline & asuhan keperawatan & \\
\hline & Mengawasi jalannya & \\
\hline & pelayanan oleh perawat & \\
\hline & kepada pasien & \\
\hline & Menanyakan & \\
\hline & masalah/kesulitan yang & \\
\hline & dihadapi perawat terkait & \\
\hline & pasien & \\
\hline
\end{tabular}

Berdasarkan data yang diperoleh dari ketiga responden tentang teknik atau cara supervisi di RSUD Panembahan Senopati Bantul dapat diambil tema yakni supervisi dilakukan dengan teknik supervisi langsung dan tidak langsung sekaligus.

Hasil pengamatan dengan checklist observasi menunjukkan hal yang berbeda dengan hasil wawancara. Penilaian teknik supervisi dengan observasi pada poin nomor 4 sampai dengan 14 Sebanyak 17 kali observasi momen supervisi pada Oktober 2015 dengan tiap observasi menunjukkan hasil bahwa dari 17 kali pelaksanaan supervisi yang dilakukan Oktober 2015 masih ada yang tidak dilakukan sebagaimana mestinya karena masih terdapat poin checklist yang tidak dilaksanakan dalam supervisi. Checklist nomor 5 sampai 8 misalnya, yang merupakan contoh item penilaian teknik supervisi tidak langsung, masih terdapat nilai ketidakpatuhan. Checklist nomor 9 misalnya, tentang pengawasan pemakaian APD sebagai salah satu contoh item penilaian supervisi langsung juga belum dilakukan oleh seluruh supervisor (hanya 5 saja dari 17 kali pelaksanaan supervisi yang melakukan pengawasan pemakaian APD).

Menurut hasil pengamatan, supervisi keperawatan di RSUD Panembahan Senopati Bantul belum dilakukan secara langsung dan tidak langsung, mayoritas masih melaksanakan supervisi secara tidak langsung saja. Padahal hasil wawancara menyimpulkan bahwa pelaksanaan supervisi dilakukan langsung dan tidak langsung sekaligus. Hal ini menunjukkan perbedaan antara kenyataan di lapangan dengan hasil wawancara.

\section{Area Supervisi}

Data penelitian tentang area supervisi diperoleh melalui hasil wawancara dan observasi dengan checklist pada poin ke 2. Hasil coding wawancara dapat dilihat pada Tabel 5. Tabel wawancara 5 menunjukkan belum adanya kesamaan pemahaman antar supervisor tentang cakupan area yang harus disupervisi. Hasil observasi tentang pelaksanaan supervisi pada checklist pengamatan tabel 3 dimana dari 17 kali pelaksanaan supervisi ada 11 pelaksanaan yang tidak menjalankan supervisi sesuai area yang ditetapkan dan hanya ada 6 pelaksanaan yang menjalankan supervisi sesuai area yang ditetapkan. Hal ini berarti bahwa berdasarkan hasil wawancara dan hasil observasi didapatkan data bahwa supervisi keperawatan di RSUD Panembahan Senopati Bantul belum dilakukan dengan baik sebab belum terdapat kesamaan persepsi antar supervisor sehingga 
supervisi yang dilakukan belum mencakup keseluruhan area yang telah ditentukan.

Tabel 5. Hasil Coding Wawancara Area Supervisi

\begin{tabular}{|c|c|c|}
\hline Keterangan & $\begin{array}{l}\text { Axial Coding } \\
\text { (Subtema) }\end{array}$ & Tema \\
\hline Responden 1 & $\begin{array}{l}\text { Perawat dan askep } \\
\text { yang bertugas, } \\
\text { masalah yang } \\
\text { dihadapi, meliputi } \\
\text { semua uni yang } \\
\text { memberikan } \\
\text { pelayanan kesehatan } \\
\text { mulai poliklinik, } \\
\text { hemodialisa, UGD, } \\
\text { ICU, dan bangsal } \\
\text { rawat inap }\end{array}$ & $\begin{array}{l}\text { Belum ada } \\
\text { kesamaan } \\
\text { pemahaman }\end{array}$ \\
\hline Responden 2 & $\begin{array}{l}\text { Perawat dan askep } \\
\text { yang bertugas, } \\
\text { tempat supervise } \\
\text { yakni UGD, dan } \\
\text { bangsal rawat inap }\end{array}$ & $\begin{array}{l}\text { antar supervisor } \\
\text { tentang area } \\
\text { supervisi }\end{array}$ \\
\hline Responden 3 & $\begin{array}{l}\text { Perawat dan askep } \\
\text { yang bertugas, } \\
\text { tempat supervise } \\
\text { yakni UGD, ICU, } \\
\text { dan bangsal rawat } \\
\text { inap }\end{array}$ & \\
\hline
\end{tabular}

\section{Hambatan Pelaksanaan Supervisi}

Data penelitian mengenai hambatan pelaksanaan supervisi diperoleh dari hasil wawancara terhadap supervisor. Hasil penelitian tersebut dapat dilihat pada tabel 6. Berdasarkan tabel 6 dapat dilihat bahwa pada pelaksanaan supervisi keperawatan di RSUD Panembahan Senopati Bantul terdapat hambatan pelaksanaan yang berupa hambatan internal dan eksternal. Hambatan internal meliputi faktor motivasi yang kurang dan bahkan cenderung menurun (demotivasi), sedangkan hambatan eksternal berupa beban pekerjaan lain di rumah sakit selain sebagai supervisor (ada beban kerja ganda) serta apresiasi rumah sakit khususnya yang berupa honorarium masih dirasa kurang.
Tabel 6. Hasil Coding Wawancara Hambatan

Pelaksanaan Supervisi

\begin{tabular}{lll}
\hline Keterangan & $\begin{array}{l}\text { Axial Coding } \\
\text { (Subtema) }\end{array}$ & \multicolumn{1}{c}{ Tema } \\
\hline Responden 1 & $\begin{array}{l}\text { Motivasi kurang } \\
\text { Kurang } \\
\text { bersemangat }\end{array}$ & $\begin{array}{l}\text { Terdapat } \\
\text { hambatan }\end{array}$ \\
& melakukan & internal dan \\
& supervise & eksternal \\
& Apresiasi dari pihak & tentang \\
& manajemen & pelaksanaan \\
& terhadap supervisor & supervise. \\
Responden 2 & dirasa masing & Hambatan \\
& kurang, khususnya & nternal meliputi: \\
& dalam hal & demotivasi. \\
& honorarium & Hambatan \\
& Beban kerja di & eksternal \\
& rumah sakit selain & meliputi: beban \\
& sebagai supervisor & kerja ganda, \\
& yang dirasa cukup & apresiasi dan \\
& berat & honorarium \\
& Tidak senang & yang dirasa \\
menjadi supervisor & kurang. \\
& Tidak ada motivasi & \\
\hline Responden 3 & & \\
\hline
\end{tabular}

Tabel 7. Hasil Coding Wawancara Program Monitor Evaluasi Supervisi

\begin{tabular}{|c|c|c|}
\hline Keterangan & $\begin{array}{l}\text { Axial Coding } \\
\text { (Subtema) }\end{array}$ & Tema \\
\hline Responden 1 & $\begin{array}{l}\text { Belum ada evaluasi } \\
\text { antara supervior } \\
\text { dan pihak } \\
\text { manajemen RS } \\
\text { sampai saat ini }\end{array}$ & $\begin{array}{l}\text { Belum ada } \\
\text { program monitor } \\
\text { dan evaluasi }\end{array}$ \\
\hline Responden 2 & $\begin{array}{l}\text { Tidak jelas dan } \\
\text { belum pernah } \\
\text { diadakan }\end{array}$ & $\begin{array}{l}\text { pelaksanaan } \\
\text { supervise oleh } \\
\text { pihak }\end{array}$ \\
\hline Responden 3 & $\begin{array}{l}\text { Belum ada kegiatan } \\
\text { monitor evaluasi } \\
\text { atau follow up dari } \\
\text { manajemen RS }\end{array}$ & $\begin{array}{l}\text { manajemen } \\
\text { rumah sakit. }\end{array}$ \\
\hline
\end{tabular}

\section{Monitor dan Evaluasi Supervisi}

Data mengenai program monitor evaluasi supervisi dapat dilihat pada tabel 7. Berdasarkan tabel 7 diketahui bahwa ketiga responden penelitian samasama menyebutkan bahwa selama ini belum ada kegiatan monitor atau follow up supervisi keperawatan di RSUD Panembahan Senopati Bantul sehingga hal ini menjadi tema yang dapat diambil dari hasil wawancara 


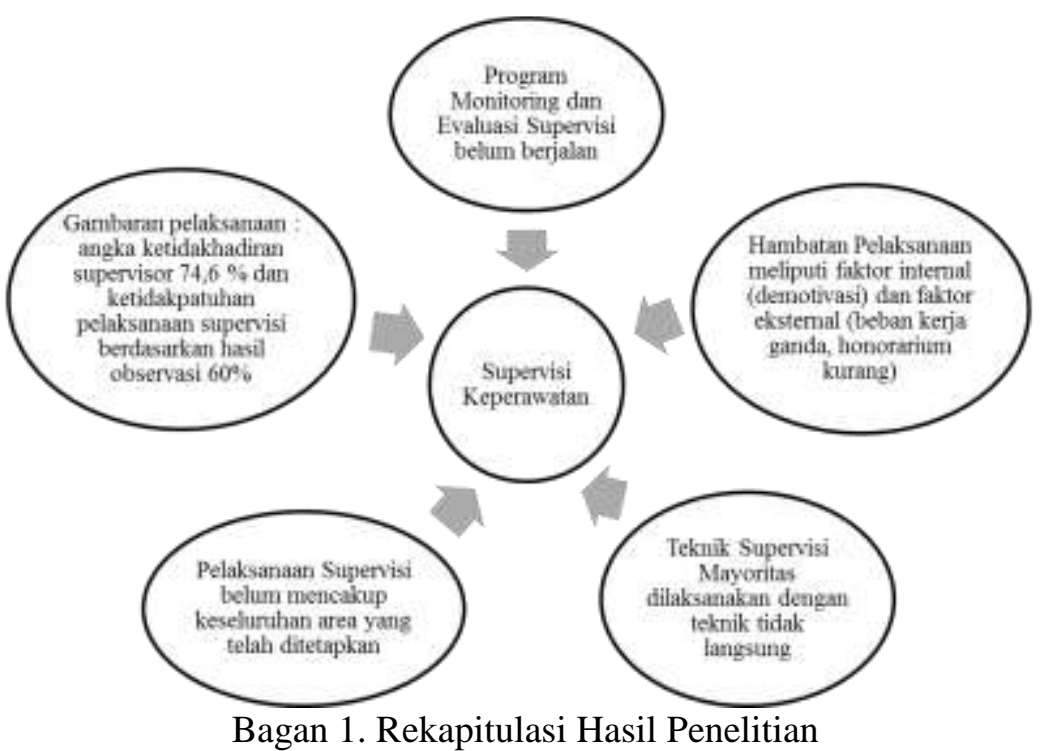

tentang program monitor evaluasi bahwa belum ada program monitor dan evaluasi pelaksanaan supervisi keperawatan oleh pihak manajemen rumah sakit. Hasil penelitian disajikan satu dalam bagan 1 .

\section{SIMPULAN}

Berdasarkan hasil penelitian tentang evaluasi pelaksanaan supervisi keperawatan di RSUD Panembahan Senopati Bantul dapat diambil kesimpulan supervisi dilaksanakan sebanyak 17 kali dari 67 supervisi yang terjadwal $(25,46 \%)$. Berdasarkan hasil observasi pelaksanaan supervisi ditemukan tingkat ketidakpatuhan supervisor dalam menjalankan supervisi sesuai SOP yang tinggi, yakni terdapat 9 item penilaian yang tidak patuh dari 15 item yang dinilai pada checklist observasi. Supervisi keperawatan di RSUD Panembahan Senopati Bantul belum dilaksanakan dengan seharusnya. Supervisi keperawatan di RSUD Panembahan Senopati Bantul menurut hasil wawancara dengan supervisor dilaksanakan dengan teknik langsung dan tidak langsung sekaligus, sedangkan menurut hasil observasi, mayoritas dilaksanakan dengan teknik tidak langsung saja. Hal ini menunjukkan kebelumpahaman supervisor tentang kegiatan supervisi dan uraian tugas supervisor.

Supervisi keperawatan di RSUD Panembahan Senopati Bantul belum menjangkau seluruh area supervisi yang telah ditetapkan. Hambatan supervisi keperawatan di RSUD Panembahan Senopati Bantul berupa hambatan internal dan eksternal. Hambatan internal berupa faktor demotivasi, sedangkan hambatan eksternal yakni beban pekerjaan ganda dan penghargaan rumah sakit kepada supervisor dirasa masih kurang, khususnya dalam hal honorarium. Belum terdapat program rutin dan berkala tentang monitor dan evaluasi kegiatan supervisi keperawatan di RSUD Panembahan Senopati Bantul karena belum terdapat peraturan atau kebijakan yang mengaturnya.

\section{DAFTAR PUSTAKA}

1. Aditama, Chandra Yoga. (2004). Manajemen AdministrasiRumah Sakit. Jakarta: Penerbit Universitas Indonesia (UI-Press)

2. Ahaddyah, Rachma Melati. (2012). Analisis Pelaksanaan Supervisi Keperawatan di RSUD Kota Depok tahun 2012. Program Ilmu Kesehatan Masyarakat. Fakultas Kesehatan Masyarakat Universitas Indonesia.

3. Badi'ah, Atik. (2009). Hubungan Motivasi Perawat dengan Kinerja Perawat di Ruang Rawat Inap RSUD Panembahan Senopati tahun 2008. Poltekes Kesehatan Yogyakarta.

4. Bara, M. (2014). Hubungan Motivasi Perawat dengan Pelaksanaan Pendokumentasian Asuhan Keperawatan di Ruang Rawat Inap RSUD Pasar Rebo. Jurnal Health Quality Vol 5 No 1. Halaman 1-66 
5. Depkes R.I. (2008). Modul Manajemen dan Pemberian Asuhan Keperawatan di Unit Ruang Rawat Rumah Sakit. Bandung: Depkes

6. Gibson. (2000). Organisasi, Perilaku, Struktur dan Proses. Alih bahasa: Maya Sari. Edisi ke-5. Cetakan ke-3. Jakarta: Penerbit Erlangga.

7. Gillies, D.A. (1996). Nursing manajement : system approach. Chigago : Lippincott Company.

8. Hasibuan, Malayu. (2003). Manajemen : Dasar, Pengertian dan Masalah. Jakarta : PT Bumi Aksara.

9. Huber, D. (2006). Leadership and Nursing Care Management. 3rd. Philadelphia: W.B. Saunders Company.

10. Idayu, Widyana. (2012). Hubungan Motivasi Kerja dengan Kinerja Perawat dalam Memberikan Asuhan Keperawatan di Ruang Rawat Inap Rumah Sakit Umum Daerah Langsa. Program Studi Keperawatan. Universitas Sumatera Utara.

11. Ilyas, Y. (2002) Kinerja: Teori penilaian dan penelitian. Jakarta: FKM UI.

12. Manullarang. (2001). Manajemen Personalia. Yogyakarta. Gajah Mada University Press.

13. Moerdiyanto. (2004). Teknik Monitoring dan Evaluasi dalam Rangka Memperoleh Informasi untuk Pengambilan Keputusan Manajemen. Jakarta.

14. Mua EL. (2011). Peningkatan Kepuasan dan Kinerja Perawat Melalui Supervisi Kepala Ruangan. Jurna Keperawatan Indonesia,14(3), 171-178.

15. Nainggolan, Mei J (2010). Pengaruh Pelaksanaan Supervisi Kepala Ruangan terhadap Kinerja Perawat
Pelaksana di Rumah Sakit Islam Malahayati Medan. Medan : Universitas Sumatera Utara.

16. Navsia, Natasia. (2014). Faktor yang Mempengaruhi Kepatuhan Pelaksanaan SOP Asuhan Keperawatan di ICU-ICCU RSUD Gambiran Kota Kediri. Program Magister Manajemen Rumah Sakit. Fakultas Kedokteran Universitas Brawijaya Malang.

17. Nursalam. (2011). Manajemen Keperawatan: Aplikasi dalam Praktik Keperawatan Profesional. Jakarta: Salemba Mediaka

18. Purweni, Sri. (2015). Perbedaan Tingkat Kepuasan dan Kinerja Perawat terhadap Penerapan Supervisi Langsung dan Tidak Langsung di RS Islam Sultan Agung Semarang. Tesis. Program Studi Ilmu Keperawatan. Universitas Diponegoro Semarang.

19. Robbins, Stephen. (2006). Perilaku Organisasi. Edisi Terjemahan. Jakarta : Erlangga

20. Siregar, Marni. (2008). Pengaruh Motivasi Terhadap Kinerja Perawat Pelaksana di Ruang Rawat Inap. Diambil pada tanggal 10 Desember 2015 dari http://library.usu.ac.id/index.php?option=com_journal _review\&id=13824\&task=view

21. Sudaryanto, A \&Supratman. (2008). Model-Model Supervisi Keperawatan Klinik. Diambil pada tanggal 29 Mei $2016 \quad$ dari http://eprints.ums.ac.id/1132/1/4h.pdf.

22. Wiyana, Muncul. (2008). Supervisi dalam Keperawatan. Diambil pada tanggal 10 Juni 2016. Dari http://www.akpermadiun.ac.id/index.php?link=artikel dtl.php\&id=3 